\title{
Social housing programme of Selangor Zakat Board of Malaysia and housing satisfaction
}

\author{
Mohammad Abdul Mohit • Nurul Nazyddah
}

Received: 20 November 2009/Accepted: 23 March 2011/Published online: 19 April 2011

(C) The Author(s) 2011. This article is published with open access at Springerlink.com

\begin{abstract}
Social housing in Malaysia is provided through the public and private sectors. Recently, the Selangor Zakat Board (SZB) has started to provide social housing in the state of Selangor, Malaysia. Up to 2007, a total of 906 units have been delivered under its different programmes. This paper evaluates these programmes by adopting the housing satisfaction model which is currently used as a customer satisfaction tool for public/private housing in many local governments in the UK and USA. The main purpose of this paper is to identify the types of housing programmes adopted by SZB and examine beneficiaries' housing satisfaction in each programme on a comparative plane. In order to examine housing satisfaction, five objective components of satisfaction-housing unit features, housing unit support services, the social environment, public facilities and neighbourhood facilities-were analysed through beneficiaries' levels of satisfaction which were measured by applying a Likert scale. The findings of the paper indicate that SZB has been successful in providing a moderate level of satisfaction with the housing unit. However, the existence of variable levels of satisfaction with other components implies that there is still scope to enhance residents' satisfaction with those components.
\end{abstract}

Keywords Social housing - Housing satisfaction - Housing unit features · Housing unit support services $\cdot$ Public and neighbourhood facilities $\cdot$ Social environment

\section{Introduction}

In Malaysia, social housing ${ }^{1}$ is usually provided through the public and private sectors. Public-sector provisions are mostly concentrated in large urban centres such as Kuala Lumpur and George Town, but also in the rural areas, while the private sector operates in urban and suburban areas. Recently, the Selangor Zakat Board (SZB), as a third sector, has

${ }^{1}$ Social housing is low-cost housing which has an amount of subsidy involved in its construction.

M. A. Mohit $(\bowtie) \cdot$ N. Nazyddah

Kulliyyah (Faculty) of Architecture and Environmental Design (KAED), International Islamic

University Malaysia (IIUM), Gombak, 53100 Kuala Lumpur, Malaysia

e-mail: mohd.mohit@gmail.com 
Table 1 Distribution of Zakat funds by beneficiary categories, 2006 and housing expenditures during JulySept'07 by SZB

\begin{tabular}{llll}
\hline Beneficiary category & Distribution (RM) & Percentage (\%) & $\begin{array}{l}\text { Amount spent on housing } \\
\text { (July-Sept'07) RM'000' }\end{array}$ \\
\hline The Indigent $^{\mathrm{a}}$ & $2,589,451.00$ & 1.94 & $124.6(2.5 \%)$ \\
The Needy $^{\mathrm{a}}$ & $38,556,208.00$ & 28.9 & $2048.2(14.0 \%)$ \\
The Collectors $^{\mathrm{a}}$ & $19,739,056.00$ & 14.8 & - \\
The Reconciled $^{\mathrm{a}}$ & $7,649,712.00$ & 5.73 & $313.8\left(8.5^{\mathrm{a}}\right)$ \\
Ransoming of Slaves & $683,428.00$ & 0.51 & - \\
The Debtors & $9,999,254.00$ & 7.49 & - \\
For the sake of God & $53,707,577.00$ & 40.4 & - \\
The Wayfarer & $445,736.00$ & 0.03 & $2,486.6(11.2)$ \\
Total & $133,654,172.31$ & 100.00 &
\end{tabular}

Source: SZB (2008)

${ }^{a}$ Category which contains housing beneficiaries

started to participate in the provision of social housing in the state of Selangor, Malaysia. Till 2007, 906 units, which accounts for a little over $1 \%$ of total low-cost housing in the state, have been delivered under its different programmes.

Selangor Zakat Board (SZB) is a wholly owned subsidiary of Selangor Islamic Religious Council (SIRC) with a paid-up capital of RM (Ringgit Malaysia) 0.50 (US\$0.16) million. ${ }^{2}$ It was established in 1994 in order to manage the zakät system ${ }^{3}$ in Selangor, but it started its operation in October 1995. The main function of SZB is to organise the collection of zakat payments in Selangor on behalf of SIRC and also distribute zakat funds, in accordance with religious principles, to designated beneficiary categories. Its purpose is to improve the quality of life of all the beneficiaries in the state. The collection of zakat rose from RM15.8 (US\$4.90) million in 1995 to RM159.8 (US\$50.0) million in 2006, a tenfold increase over a 12-year period. SZB takes a Community Development Approach to allocate the zakat funds through its social, economic, society, and human development programmes. Housing and shelter activities fall under the Social Development Programme. Related schemes under this programme are (a) construction/improvement of individual houses; (b) construction of cluster housing; (c) rental housing for transit dwellers; and (d) an old folks' home. Individual houses are those dwellings (in dilapidated conditions) that are privately owned and whose owners are too poor to improve them. SZB provides a maximum of RM17,000 (US\$5,300) for their improvement. For cluster housing, SZB procures land from the state government and constructs single-storey cluster units for delivery to the poor. Transit houses are mainly high-rise flats rented by SZB to accommodate poor families in urban areas. Old folks' homes are rented by SZB to house the

\footnotetext{
2 Exchange rate US\$1.00 $=$ RM3.20.

3 Zakat (tithe or poor-due) is an annual obligatory religious levy or transfer payments by well-off Muslims to the destitute and the needy in a Muslim society. In religious terminology, it (zakat) is the part of wealth which the rich have been ordained to spend on deserving recipients at prescribed rates as per rules laid down in the Islamic sources. It is an instrument of redistribution of income and wealth in Islam, intended to eradicate poverty altogether by spending for the welfare of the poor and the destitute (Al-Qardawi and Allama 2006, p. 67).
} 
elderly and aged poor. SZB applies a set of criteria based on income, family size and local leaders' recommendation to decide who should benefit from all their housing schemes.

The beneficiary category 'for the sake of God' accounts for the largest allocation, followed by the 'needy' and 'collectors'. The housing expenditure of SZB is mainly confined to three categories: the 'indigent', the 'needy' and the 'reconciled', together accounting for RM2.5 million every 3 months or about RM10.0 million per year (Table 1). SZB spends the largest share of its housing expenditure on the needy.

The provision of social housing by the public and private sectors has been widely studied in Malaysia (Razali 1993; Tan 1980; Salleh 2008). So far, however, no study has been done on the effectiveness of the zakat-funded housing programmes. This paper, therefore, intends to evaluate the important SZB housing programmes. It does so by adopting the housing satisfaction model which is currently used as a customer satisfaction tool for public/private housing by many local governments in the UK and USA.

\section{Perspectives on housing satisfaction literature}

Housing satisfaction is defined as the degree of contentment experienced by an individual or a family member with regard to the current housing situation. It is basically a noneconomic and normative quality evaluation approach which is used to assess the quality of housing units and services. The assessment is based on a 'minimum standard or intervention points' beyond which something needs to be done to avert further deterioration of the housing condition (Ogu 2002). The idea of housing satisfaction has been used as a guide by many planners, designers, developers and policy-makers who attempt to provide housing to a variety of people (Ukoha and Beamish 1997). It has been used as (a) a key predictor of an individual's perceptions of general quality of life; (b) an indicator of incipient residential mobility, and has thereby altered housing demands and affected neighbourhood change; (c) an ad hoc evaluative measure for judging the success of developments constructed by private and public sectors; and (d) a tool to assess residents' perceptions of inadequacies in their current housing environment in order to improve the status quo (Djebarni and Al-Abed 2000). Recently, the neighbourhood component of housing satisfaction has been used to evaluate the physical form of two US cities (Yang 2008).

Theoretical perspectives on housing satisfaction usually consider the difference between households' actual and their desired/aspired housing and neighbourhood situations (Galster 1987). Individuals usually make judgements about housing conditions in light of their needs and aspirations, so any incongruence between the two may lead to dissatisfaction. Rossi (1955) argues that housing needs and aspirations change as households progress through their life cycle, leading to residential dissatisfaction at some stage. They respond to this dissatisfaction through migration. Hence, migration is regarded as an adjustment process to enhance residential satisfaction. Morris and Winter $(1975,1978)$ introduced the idea of "housing deficit" and conceptualised housing satisfaction as a dynamic process. In their housing adjustment model of residential mobility, they argue that households judge their housing conditions according to two types of norms, personal or cultural, which may not coincide. An incongruity between the actual housing satisfaction and housing norms results in a housing deficit. That, in turn, gives rise to housing dissatisfaction, leading to some form of housing adjustment. It may be in situ, such as revising one's housing needs and aspirations in order to reconcile the incongruity, or improving one's housing 
conditions through remodeling. Alternatively, the adjustment may be made by moving away to bring the housing into conformity with one's aspirations or needs.

Housing satisfaction is a complex construct, affected by a variety of environmental and socio-demographic variables ( $\mathrm{Lu} \mathrm{1999).} \mathrm{Studies} \mathrm{on} \mathrm{housing} \mathrm{satisfaction} \mathrm{have} \mathrm{therefore}$ used a number of variables representing housing and neighbourhood characteristics, individuals' socio-demographic attributes as well as their perceptions of the housing and neighbourhood conditions that affect housing satisfaction. Jaafar et al. (undated) observed that project type, house price and length of residency significantly influenced housing satisfaction among the residents of Penang Development Corporation's projects. Ukoha and Beamish (1997) reported that while the residents of public housing in Abuja, Nigeria, were satisfied with neighbourhood facilities, they were dissatisfied with structure types, building features, housing conditions and management.

Husna and Nurizan (1987) found that while the residents of public low-cost housing in Kuala Lumpur, Malaysia, were satisfied with the services rendered by the city-hall workers and with the neighbourhood factors, a large proportion of them felt dissatisfied with housing unit features. Nurizan (1993) reported that whereas the residents of low-cost housing in Johor Bahru were satisfied with public transport and the distance of housing from the city, they were not satisfied with the size, rent and crowding in their houses. Djebarni and Al-Abed (2000) observed that the residents of public low-income housing in Sana'a attach great importance to the level of satisfaction with their neighbourhoods, particularly with regard to privacy, which reflects the cultural background of Yemeni society. Lane and Kinsey (1980) reported that housing characteristics were more crucial determinants than demographic characteristics of housing occupants. Ogu (2002) studied urban residential satisfaction of inhabitants living in core, intermediate, suburban and planned areas of Benin City, Nigeria. The author found that while most housing component variables generally contributed positively to residential satisfaction, environmental variables made negative contributions. Salleh (2008) investigated housing satisfaction in two states, Pulau Pinang and Terengganu, and found that the neighbourhood factors were the predominant ones affecting the levels of housing satisfaction in private low-cost housing in Malaysia. Mohit et al. (2010) have found that the residents of the newly designed public low-cost housing in Kuala Lumpur are moderately satisfied with housing support services, followed by public and neighbourhood facilities and then by housing features and the social environment, which have a higher percentage of respondents with a low level of satisfaction. Alison et al. (2002), after analysing English housing data, concluded that although socio-demographic factors were much less important than residential perceptions in helping to predict dissatisfaction, the type of neighbourhood remained a significant independent predictor of dissatisfaction even when residents' views were taken into account. Dwellers in private low-cost housing in and around Bangkok, Thailand, were generally more satisfied with their housing units than with environmental facilities (Savasdisara et al. 1989).

Some studies reveal that housing satisfaction is much higher among homeowners than renters (Lu 1999; Loo 1986). Elsinga and Hoekstra (2005) reported that homeowners in seven out of eight European countries are more satisfied with their housing situation than tenants are, and that only in one country do homeowners and tenants display a similar level of satisfaction. Even when the quality of the housing unit is similar, owner-occupiers are likely to be more satisfied than renters. This might be because home ownership gives people a sense of 'self-gratification', making them proud and thereby satisfied with their dwelling units (Kaitilla 1993). Nevertheless, Russell (2008a, b) found that after middle age, residential satisfaction among US tenants increases dramatically. Barcus (2004) found 
that tenure shift from renting to owning is the only significant variable in predicting residential satisfaction of American urban-rural migrants; individual migrant characteristics and their motivations offered little explanation for the variation in residential satisfaction. Lu (2002) found similar results when modelling the residential satisfaction of intra- and inter-regional migrants. The most likely explanation is that renters have less control over their housing environment and in general have a lower housing quality (Loo 1986).

Housing satisfaction also tends to vary for public versus private housing and subsidized versus non-subsidized housing. According to Lu (1999), public renters were more likely to be satisfied because of the availability of a basic level of amenity, service and maintenance of their dwellings. However, public renters are more likely to have very low levels of neighbourhood satisfaction because of the location and density of public housing. Russell (2008a, b) found that subsidized renters in the US report higher satisfaction with their housing than similarly situated non-subsidized renters. In multi-family housing in the US, it was found that improvement and addition of dwelling elements had a clear impact on satisfaction, even in rented houses (Russell 2007).

The foregoing review indicates that while various housing, neighbourhood and household characteristics determine the level of housing satisfaction, the impacts of these variables as predictors of housing satisfaction or dissatisfaction tend to vary by housing type, tenure, country and culture. The implication is that research should be done to determine housing satisfaction in case-specific situations to guide agency policies. In Malaysia, studies on low-cost housing satisfaction have been focussed on the public and private sectors; so far, no study has investigated housing satisfaction in dwellings provided through the emerging third sector, SZB. Therefore, this paper fills a gap that currently exists in the literature on social housing in Malaysia.

\section{Objectives and research questions}

The literature on low-cost housing reveals that housing satisfaction is a complex construct and that it depends on a number of factors which require careful examination. This paper intends to investigate those factors and examine their role in the overall satisfaction, with the following objectives:

(a) To explore the types of social housing provided through Selangor Zakat Board (SZB);

(b) To examine and compare the levels of housing satisfaction perceived by the residents in the provided housing schemes;

(c) To determine the factors influencing the overall housing satisfaction levels in each category of housing;

(d) To provide recommendations that will help improve residents' levels of housing satisfaction.

Given the objectives of the study, a few research questions emerge as stated below:

(a) How do the residents in the three housing types rate their satisfaction with the fortyfive variables and five components?

(b) How do the residents' perceived levels of satisfaction differ by the housing types?

(c) What are the predictor variables and factors that can enhance the housing satisfaction levels of the residents in the three housing types? 


\section{Methodology}

Housing quality can be assessed by objective and subjective measurement. Objective measurement evaluates the physical characteristics, facilities, services and environment. Subjective measurement includes perception, satisfaction, aspiration and disappointment; it is closely related to the psycho-social aspects of a person (Nurizan and Hashim 2001).

\subsection{Selection of components and variables for measuring housing satisfaction}

Most housing satisfaction studies integrate both objective and subjective attributes for the assessment of housing satisfaction. Francescato et al. (1987) observe that housing satisfaction depends on three elements: the design, which includes its spatial organisation, layout and facilities provision; the management practices; and the surrounding social environment. Tenant satisfaction encompasses four components of satisfaction: (1) satisfaction with the dwelling unit; (2) with the services provided; (3) with the whole rent package-dwelling and services; and (4) with the neighbourhood or area (Varady and Carrozza 2000). Nurizan and Hashim (2001) reported that besides facilities in the house, basic facilities such as shops, markets, schools, clinic, mailing system, community hall and playground are important to support the daily life of the residents and enhance their quality of life. Therefore, based upon a literature review of variables that affect residents' housing satisfaction, the present study adopts a "housing satisfaction bundle" with five components and forty-five variables (Table 2).

\subsection{Sampling design}

In this study, stratified random sampling was performed to select respondents for survey. The residents of the zakäh-funded social housing estates were stratified into three categories-cluster, individual and transit. A total of 250 respondents were randomly selected for the survey (Table 3).

A structured questionnaire was used to gather data from the respondents. The form contained six sections: respondents' socio-economic and house unit information (Sect. 1); satisfaction with housing unit features (Sect. 2); satisfaction with housing unit support services (Sect. 3); satisfaction with public facilities (Sect. 4); satisfaction with social

Table 2 Components and variables selected for measuring housing satisfaction

\begin{tabular}{|c|c|c|c|c|}
\hline $\begin{array}{l}\text { Housing unit } \\
\text { features } \\
\text { (Component-1) }\end{array}$ & $\begin{array}{l}\text { Housing unit } \\
\text { support services } \\
\text { (Component-2) }\end{array}$ & $\begin{array}{l}\text { Public facilities } \\
\text { (Component-3) }\end{array}$ & $\begin{array}{l}\text { Social } \\
\text { environment } \\
\text { (Component-4) }\end{array}$ & $\begin{array}{l}\text { Neighbourhood } \\
\text { facilities } \\
\text { (Component-5) }\end{array}$ \\
\hline $\begin{array}{l}\text { Living, dining, } \\
\text { bedroom, } \\
\text { kitchen, } \\
\text { bathroom, toilet } \\
\text { and (clothes) } \\
\text { drying areas } \\
\text { (power) socket } \\
\text { points, including } \\
\text { ventilation of } \\
\text { the house }\end{array}$ & $\begin{array}{l}\text { Corridors, } \\
\text { staircase, } \\
\text { drainage, } \\
\text { garbage } \\
\text { collection, } \\
\text { lifts and fire } \\
\text { fighting } \\
\text { system }\end{array}$ & $\begin{array}{l}\text { Open space, play } \\
\text { area, parking, } \\
\text { prayer and multi- } \\
\text { purpose halls, } \\
\text { perimeter roads, } \\
\text { pedestrian } \\
\text { walkways, public } \\
\text { phone, local shops }\end{array}$ & $\begin{array}{l}\text { Noise, crime, } \\
\text { accidents, and } \\
\text { community } \\
\text { relations }\end{array}$ & $\begin{array}{l}\text { Distances to town } \\
\text { centre, school, } \\
\text { police station, } \\
\text { hospital, market, } \\
\text { shopping centres, } \\
\text { public library, } \\
\text { mosque, LRT, bus } \\
\text { and taxi stations }\end{array}$ \\
\hline
\end{tabular}

Source: Literature Review, 2009 
Table 3 Selection of sample size for questionnaire survey

\begin{tabular}{llcll}
\hline House (Category) & Entitled category & Units delivered & Sample & Sample \% of total \\
\hline Cluster & The Indigent \& Needy & $426(47.0 \%)$ & 100 & 23.4 \\
Individual & The Indigent \& Needy & $400(44.2 \%)$ & 100 & 25.0 \\
Transit & The Indigent, Needy \& Reconciled & $80(8.8 \%)$ & 50 & 62.5 \\
Total & 3 Categories & $906(100.0 \%)$ & 250 & 27.6 \\
\hline
\end{tabular}

Source: SZB (2008)

environment (Sect. 5); and satisfaction with neighbourhood facilities (Sect. 6). The level of housing satisfaction was measured on a five-point Likert scale: "1" for very dissatisfied, "2" for dissatisfied, "3" for slightly satisfied, "4" for satisfied and "5" for very satisfied.

\subsection{Satisfaction index}

The satisfaction index for a particular housing component was calculated with the following equation:

$$
\text { SIc }=\frac{\sum_{i=1}^{N} y i}{\sum_{i=1}^{N} Y i} \times 100
$$

where SIc is the satisfaction index of a respondent with component $c$ of the housing environment of a particular category, $N$ is the number of variables being scaled under $c, y i$ is the actual score by a respondent on the $i$ th variable, and $Y i$ is the maximum possible score that $i$ could have on the scale used.

\subsection{Housing satisfaction index}

The housing satisfaction index is calculated as the sum total of the component satisfaction indices (Eq. 2).

$$
H S I r=\frac{\sum_{i=1}^{N 1} d i+\sum_{i=1}^{N 2} s i+\sum_{i=1}^{N 3} p i+\sum_{i=1}^{N 4} s e i+\sum_{i=1}^{N 5} n i}{\sum_{i=1}^{N 1} D i+\sum_{i=1}^{N 2} S i+\sum_{i=1}^{N 3} P i+\sum_{i=1}^{N 4} S E i+\sum_{i=1}^{N 5} N i} \times 100
$$

where HSIr is a respondent's satisfaction with the housing environment; $N 1, N 2, N 3, N 4$ and $N 5$ are the number of variables selected for scaling under each component of housing environment; while $d i$, si, pi, sei and $n i$ represent the actual score of a respondent on the $i$ th variable in the five components. $\mathrm{Di}, \mathrm{Si}, \mathrm{Pi}, \mathrm{SEi}$ and $\mathrm{Ni}$ are the maximum possible scores for the $i$ th variable in the housing unit features, housing unit support services, public facilities, social environment and neighbourhood facilities, respectively, calculated for each category of housing.

4.5 Habitability index

$$
H I x=\frac{\sum_{i=1}^{N} a y^{\prime} x}{\sum_{i=1}^{N} A y^{\prime} x} \times 100
$$

$H I x$ represents the index of habitability (Ogu 2002) of variable $x$ and $N$ is the number of respondents, while $a y^{\prime} x$ is the actual score on the five-point scale for the $y$ th respondent on 
the $x$ th variable. ' $A$ ' represents the maximum possible score that respondent ' $y$ ' could give to variable $x$ on the five-point scale.

\section{A conceptual model of housing satisfaction}

The conceptual model used in this paper is based on the notion that housing satisfaction is a composite construct of the indices of satisfaction which respondents perceive with their housing unit features and support services, public facilities, social environment and neighbourhood facilities. According to Amerigo and Aragones (1997), once the objective attributes of the housing environment have been evaluated by the individual, they become subjective, giving rise to a certain degree of satisfaction. Subjective attributes are influenced by the subject's socio-demographic and personal characteristics as well as his/her housing quality pattern, a normative element whereby the individual compares his/her real and ideal housing environment. The model (Fig. 1) shows that the respondents' evaluation of objective attributes of housing through their socio-economic and demographic characteristics become subjective attributes. These can be captured in the five components of housing satisfaction. Together, these five components form the basis of housing satisfaction of the residents living in the three types of housing.

\section{Analysis and findings}

\subsection{Demographic and socio-economic characteristics of the respondents}

As Table 4 shows, a little over $75 \%$ of the respondents are male heads of families and the rest are females. Single parents constitute nearly $25 \%$ of the total number of families. The majority of respondents (ranging from 64 to 84\%) of all housing schemes are between 31 and 40 years of age. Whereas the percentage of elderly family heads in transit housing is low, it is significant in both individual and cluster housing types. Although the average bedroom occupancy is less than 2.0 in all housing schemes, a large percentage (58-66\%) have $6+$ family members. While only $14 \%$ of the respondents in transit housing have no formal education, the percentage is significant (30\% each) in cluster and individual housing. Between 40 and $42 \%$ of the respondents in the three housing schemes have a low level of education. Their lower level of education is also reflected in the low level of family income, $<$ RM1000 ( $<$ US\$315.0), which applies to 84-90\% of the respondents in the three housing schemes. A relatively longer length of residency is observed among people in individual housing compared to the cluster housing residents. For most of the transit dwellers, the length of residency is short because this programme is newer than the others (Table 4).

Although $40 \%$ of the transit housing respondents have no private transport, $28 \%$ and $18 \%$ of the cluster and individual housing residents, respectively, do not own any means of transport either. While $56 \%$ of those in individual housing and $52 \%$ of the cluster housing residents own motorised transport, only $36 \%$ of the transit residents do. Transit dwellers have a higher percentage $(82 \%)$ of working wives than cluster $(64 \%)$ and individual $(60 \%)$ residents. 


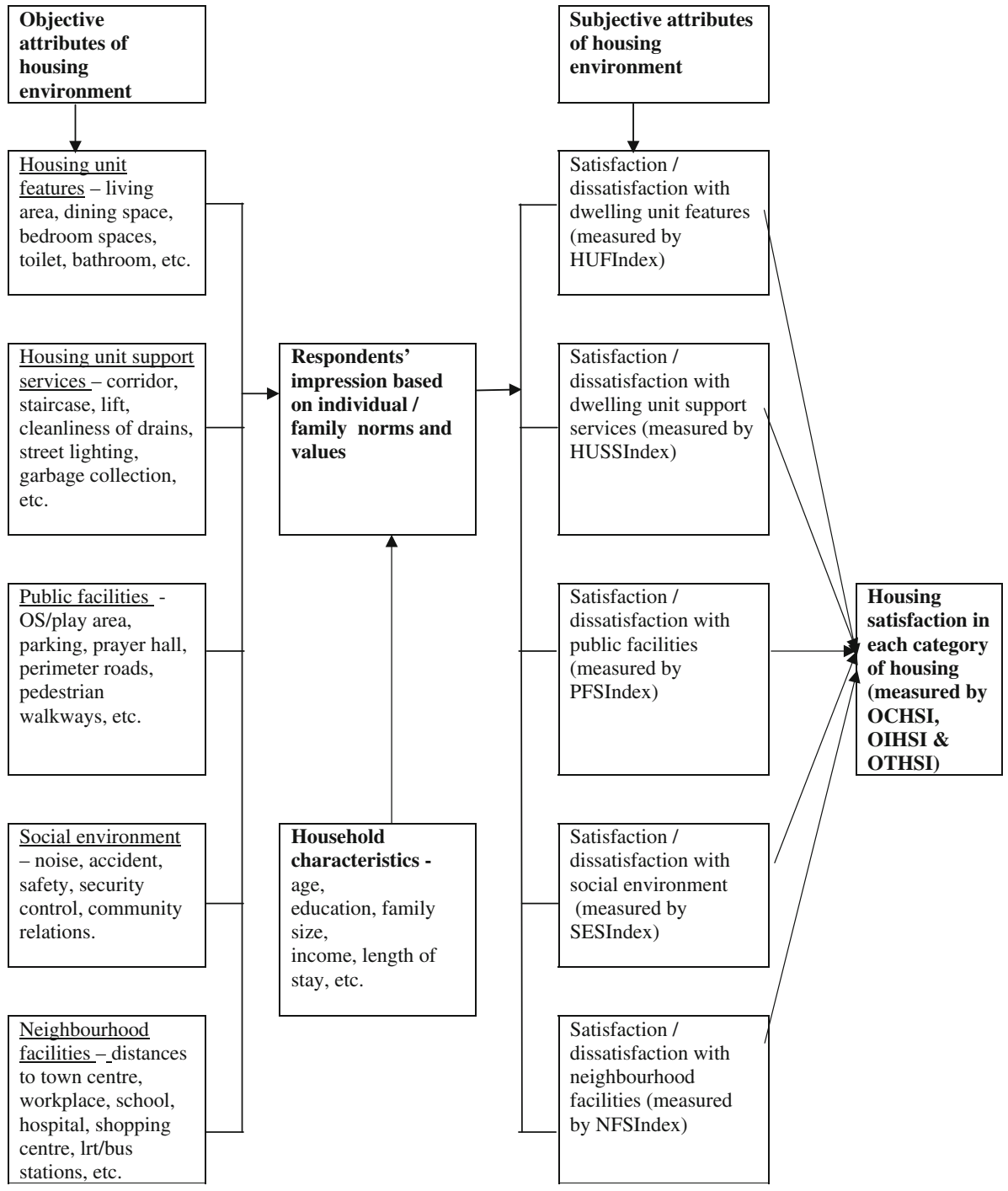

Fig. 1 Relationship between objective and subjective attributes of housing environment to determine housing satisfaction. Notes: HUFSIndex, Housing unit features satisfaction index; HUSSSIndex, Housing unit support service satisfaction index; PFSIndex, Public facilities satisfaction index; SESIndex, Social environment satisfaction index; NFSIndex, Neighbourhood facilities satisfaction index; OCHSI, Overall Cluster Housing Satisfaction Index; OIHSI, Overall Individual Housing Satisfaction; OTHSI, Overall Transit Housing Satisfaction Index

\subsection{Analysis of housing satisfaction}

Overall housing satisfaction rated by three resident groups indicates a mean value of a little over slightly satisfied or a lower level of satisfaction than the moderate level which is defined with a mean value of 3.5 (Table 5). For the housing unit component, all residents have expressed moderate satisfaction, with transit and individual housing residents rating it 
Table 4 Respondents' demographic and socio-economic characteristics

\begin{tabular}{|c|c|c|c|c|c|c|}
\hline \multirow[t]{2}{*}{ Socio-demographic characteristics } & \multicolumn{2}{|l|}{ Cluster } & \multicolumn{2}{|c|}{ Individual } & \multicolumn{2}{|l|}{ Transit } \\
\hline & $f$ & $\%$ & $f$ & $\%$ & $f$ & $\%$ \\
\hline \multicolumn{7}{|l|}{ Gender } \\
\hline Male & 78 & 78 & 78 & 78 & 38 & 76 \\
\hline Female & 22 & 22 & 22 & 22 & 12 & 24 \\
\hline \multicolumn{7}{|l|}{ Marital status } \\
\hline Married & 78 & 76 & 76 & 76 & 37 & 74 \\
\hline Unmarried & 2 & 2 & 2 & 2 & 1 & 2 \\
\hline Single parent & 24 & 24 & 22 & 22 & 12 & 24 \\
\hline \multicolumn{7}{|l|}{ Age } \\
\hline $25-30$ & - & - & 1 & 2 & 1 & 2 \\
\hline $31-40$ & 4 & 4 & 6 & 6 & 13 & 26 \\
\hline $41-60$ & 74 & 74 & 78 & 78 & 32 & 64 \\
\hline$>60$ & 22 & 22 & 14 & 14 & 2 & 4 \\
\hline \multicolumn{7}{|l|}{ Family size/persons per bedroom } \\
\hline $1-5$ persons & 42 & 42 & 34 & 34 & 18 & 36 \\
\hline $6-10$ persons & 48 & 48 & 52 & 52 & 24 & 48 \\
\hline $10>$ persons & 10 & 10 & 14 & 14 & 8 & 16 \\
\hline Average family size/Bedroom occupancy & $5.7 / 1.9$ & - & $5.5 / 1.8$ & - & $5.8 / 1.9$ & - \\
\hline \multicolumn{7}{|l|}{ Educational level } \\
\hline No formal education & 30 & 30 & 30 & 30 & 7 & 14 \\
\hline Standard (1-6) & 26 & 26 & 36 & 36 & 12 & 24 \\
\hline Lower secondary (1-3) & 16 & 16 & 4 & 4 & 9 & 18 \\
\hline Upper secondary & 6 & 6 & 8 & 8 & 10 & 20 \\
\hline Missing & 22 & 22 & 22 & 22 & 12 & 24 \\
\hline \multicolumn{7}{|l|}{ Monthly family income } \\
\hline$<\mathrm{RM} 750$ & 70 & 70 & 77 & 77 & 38 & 78 \\
\hline RM750-RM1000 & 24 & 24 & 7 & 7 & 5 & 10 \\
\hline RM1000-RM1500 & 6 & 6 & - & - & 2 & 4 \\
\hline \multicolumn{7}{|l|}{$>$ RM1500 } \\
\hline No income & - & - & 16 & 16 & 4 & 8 \\
\hline \multicolumn{7}{|l|}{ Employment sector } \\
\hline Government & 2 & 2 & 4 & 4 & - & - \\
\hline Private & 4 & 8 & 4 & 4 & 1 & 2 \\
\hline Own business & 46 & 46 & 36 & 36 & 23 & 46 \\
\hline Others & 42 & 42 & 40 & 40 & 22 & 44 \\
\hline Not working (Unemployed) & 2 & 2 & 16 & 16 & 4 & 8 \\
\hline \multicolumn{7}{|l|}{ Length of residency (years) } \\
\hline $1-2$ & 0 & 0 & 2 & 2 & 33 & 66 \\
\hline $3-4$ & 4 & 4 & 2 & 2 & 10 & 20 \\
\hline $5-6$ & 20 & 20 & 8 & 8 & 7 & 14 \\
\hline $7-8$ & 62 & 62 & 24 & 24 & 0 & 0 \\
\hline 9 and above & 12 & 12 & 64 & 64 & 0 & 0 \\
\hline
\end{tabular}


Table 4 continued

\begin{tabular}{|c|c|c|c|c|c|c|}
\hline \multirow[t]{2}{*}{ Socio-demographic characteristics } & \multicolumn{2}{|c|}{ Cluster } & \multicolumn{2}{|c|}{ Individual } & \multicolumn{2}{|c|}{ Transit } \\
\hline & $f$ & $\%$ & $f$ & $\%$ & $f$ & $\%$ \\
\hline \multicolumn{7}{|l|}{ Vehicle owned } \\
\hline Motorcycle & 16 & 16 & 26 & 26 & 6 & 12 \\
\hline Car & 36 & 36 & 30 & 30 & 12 & 24 \\
\hline Bicycle & - & - & 2 & 2 & 1 & 2 \\
\hline None & 28 & 28 & 18 & 18 & 20 & 40 \\
\hline \multicolumn{7}{|l|}{ Working wives } \\
\hline Yes & 64 & 64 & 60 & 60 & 42 & 84 \\
\hline No & 36 & 36 & 38 & 38 & 8 & 16 \\
\hline
\end{tabular}

Source: Field Survey, 2009

slightly higher than the cluster group. Transit housing residents have expressed dissatisfaction with the (clothes) drying area and very low satisfaction with the dining space. While individual housing residents gave the bedroom-3, dining and kitchen spaces a lower rating, cluster residents expressed very low satisfaction with socket points, kitchen, dining and living areas. On the house support component, all residents registered very low satisfaction. Whereas transit housing residents are dissatisfied with the lift, lift lobby and fire fighting facilities, they conveyed very low satisfaction with the corridors and cleanliness of drains. Both cluster and individual housing groups have low satisfaction with the garbage collection and cleanliness of the garbage house, cleanliness of drains and street lighting.

On the public facilities component, while both transit and cluster housing groups showed moderate satisfaction, individual housing residents had a lower level of satisfaction with that component. Whereas individual housing residents are dissatisfied with the public phone, both individual and cluster groups reported low satisfaction with the open space/ play area, followed by the parking area among the individual group and by the pedestrian walkways among the cluster group.

On the social environment component, while both individual and cluster housing groups registered moderate satisfaction, transit housing residents expressed low satisfaction with that component. Whereas transit housing residents are dissatisfied about the noise level and crime in their housing areas, cluster housing residents showed low satisfaction about accidents, crime and noise in their housing areas.

On the neighbourhood facilities component, although individual housing residents expressed dissatisfaction, both transit and cluster housing residents conveyed very low satisfaction with that component. Individual housing residents were dissatisfied about the distance to the town centre, workplace, LRT station, bus stop, taxi stand and fire station, but they conveyed low satisfaction with the distance to school. While transit housing residents were dissatisfied about the distance to the LRT station and public library, they expressed a low level of satisfaction about the distance to the town centre, workplace, police station, hospital/clinic, shopping centre, market, taxi stand, bus stop and fire station. Again, while people in cluster housing expressed dissatisfaction with the distance to the LRT station and taxi stand, they showed low satisfaction with the distance to the town centre, workplace, police station, shopping centres, market, public library, bus stop and fire station. 
Table 5 Distribution of residents' mean satisfaction, standard deviation and Pearson correlation $(r)$

\begin{tabular}{|c|c|c|c|c|c|c|c|c|c|c|}
\hline \multirow[t]{2}{*}{ Components } & \multirow{2}{*}{$\begin{array}{l}\text { Satisfaction } \\
\text { with }\end{array}$} & \multicolumn{3}{|c|}{ Cluster } & \multicolumn{3}{|c|}{ Individual } & \multicolumn{3}{|c|}{ Transit } \\
\hline & & Mean & SD & $\begin{array}{l}\text { Pearson } \\
(r)\end{array}$ & Mean & SD & $\begin{array}{l}\text { Pearson } \\
(r)\end{array}$ & Mean & SD & $\begin{array}{l}\text { Pearson } \\
(r)\end{array}$ \\
\hline \multirow{12}{*}{$\begin{array}{l}\text { Housing unit } \\
\text { features } \\
\text { (HUFs) }\end{array}$} & Living area & 3.4 & 0.83 & $0.31^{\mathrm{a}}$ & 3.5 & 1.11 & $0.74^{\mathrm{a}}$ & 4.0 & 0.77 & $0.68^{\mathrm{a}}$ \\
\hline & Dinning space & 3.3 & 0.76 & $0.67^{\mathrm{a}}$ & 3.2 & 1.11 & $0.81^{\mathrm{a}}$ & 3.2 & 1.01 & $0.82^{\mathrm{a}}$ \\
\hline & Kitchen space & 3.4 & 0.78 & $0.82^{\mathrm{a}}$ & 3.4 & 0.97 & $0.84^{\mathrm{a}}$ & 3.4 & 0.97 & $0.58^{\mathrm{a}}$ \\
\hline & Bedroom-1 & 3.9 & 0.54 & $0.58^{\mathrm{a}}$ & 3.7 & 0.69 & $0.66^{\mathrm{a}}$ & 4.3 & 0.54 & $0.53^{\mathrm{a}}$ \\
\hline & Bedroom-2 & 3.9 & 0.54 & $0.58^{\mathrm{a}}$ & 3.7 & 0.70 & $0.67^{\mathrm{a}}$ & 4.3 & 0.54 & $0.53^{\mathrm{a}}$ \\
\hline & Bedroom-3 & 3.7 & 0.75 & $0.71^{\mathrm{a}}$ & 3.1 & 1.25 & $0.65^{\mathrm{a}}$ & 4.0 & 0.78 & $0.68^{\mathrm{a}}$ \\
\hline & Toilet & 3.6 & 0.75 & $0.54^{\mathrm{a}}$ & 3.5 & 0.86 & $0.63^{\mathrm{a}}$ & 3.7 & 0.87 & $0.74^{\mathrm{a}}$ \\
\hline & Bathroom & 3.6 & 0.77 & $0.63^{\mathrm{a}}$ & 3.6 & 0.86 & $0.64^{\mathrm{a}}$ & 3.5 & 0.99 & $0.69^{\mathrm{a}}$ \\
\hline & $\begin{array}{l}\text { (Clothes) } \\
\text { Drying area }\end{array}$ & 3.5 & 0.99 & $0.68^{\mathrm{a}}$ & 3.6 & 0.99 & $0.67^{\mathrm{a}}$ & 2.5 & 1.16 & $0.51^{\mathrm{a}}$ \\
\hline & $\begin{array}{l}\text { (Power) Socket } \\
\text { points }\end{array}$ & 3.3 & 0.95 & $0.71^{\mathrm{a}}$ & 3.5 & 0.81 & $0.54^{\mathrm{a}}$ & 3.6 & 0.85 & $0.52^{\mathrm{a}}$ \\
\hline & Ventilation & 3.6 & 0.78 & $0.55^{\mathrm{a}}$ & 3.9 & 0.67 & $0.51^{\mathrm{a}}$ & 3.6 & 0.82 & $0.73^{\mathrm{a}}$ \\
\hline & HSEs (11) & 3.6 & 0.49 & 1.00 & 3.5 & 0.60 & 1.00 & 3.7 & 0.54 & 1.00 \\
\hline \multirow{10}{*}{$\begin{array}{l}\text { Housing unit } \\
\text { support services } \\
\text { (HUSSs) }\end{array}$} & Corridor & - & - & - & - & - & - & 3.1 & 1.04 & $0.56^{\mathrm{a}}$ \\
\hline & Staircase & - & - & - & - & - & - & 3.1 & 1.17 & $0.60^{\mathrm{a}}$ \\
\hline & Lift lobby & - & - & - & - & - & - & 2.1 & 1.19 & $0.70^{\mathrm{a}}$ \\
\hline & Lift & - & - & - & - & - & - & 2.2 & 1.22 & $0.75^{\mathrm{a}}$ \\
\hline & Fire fighting & - & - & - & - & - & - & 2.4 & 1.24 & $0.72^{\mathrm{a}}$ \\
\hline & $\begin{array}{l}\text { Cleanliness of } \\
\text { drains }\end{array}$ & 3.5 & 1.04 & $0.81^{\mathrm{a}}$ & 3.1 & 1.05 & $0.73^{\mathrm{a}}$ & 3.0 & 1.18 & $0.60^{\mathrm{a}}$ \\
\hline & Street lighting & 3.2 & 1.13 & $0.75^{\mathrm{a}}$ & 3.5 & 0.91 & $0.78^{\mathrm{a}}$ & 3.8 & 0.74 & $0.47^{\mathrm{a}}$ \\
\hline & $\begin{array}{l}\text { Garbage } \\
\text { collection }\end{array}$ & 3.2 & 1.08 & $0.81^{\mathrm{a}}$ & 3.4 & 1.22 & $0.86^{\mathrm{a}}$ & 3.7 & 0.81 & $0.42^{\mathrm{a}}$ \\
\hline & $\begin{array}{c}\text { Garbage house } \\
\text { cleanliness }\end{array}$ & 3.2 & 1.03 & $0.88^{\mathrm{a}}$ & 3.0 & 1.20 & $0.88^{\mathrm{a}}$ & 3.5 & 0.91 & $0.55^{\mathrm{a}}$ \\
\hline & HSSs (9) & 3.2 & 0.87 & 1.00 & 3.2 & 0.90 & 1.00 & 3.0 & 0.65 & 1.00 \\
\hline \multirow[t]{9}{*}{$\begin{array}{l}\text { Public facilities } \\
\text { (PFs) }\end{array}$} & $\begin{array}{l}\text { Open space/play } \\
\text { area }\end{array}$ & 3.3 & 1.04 & $0.72^{\mathrm{a}}$ & 3.0 & 1.26 & $0.76^{\mathrm{a}}$ & 3.7 & 1.02 & $0.76^{\mathrm{a}}$ \\
\hline & $\begin{array}{l}\text { Car/M'cycle } \\
\text { parking }\end{array}$ & 3.5 & 1.05 & $0.74^{\mathrm{a}}$ & 3.3 & 1.24 & $0.79^{\mathrm{a}}$ & 4.0 & 0.65 & $0.45^{\mathrm{a}}$ \\
\hline & Prayer hall & 3.7 & 0.94 & $0.68^{\mathrm{a}}$ & 4.0 & 0.63 & $0.57^{\mathrm{a}}$ & 4.1 & 0.58 & $0.66^{\mathrm{a}}$ \\
\hline & $\begin{array}{l}\text { Multi-purpose } \\
\text { hall }\end{array}$ & 3.8 & 0.75 & $0.62^{\mathrm{a}}$ & 3.5 & 0.75 & $0.61^{\mathrm{a}}$ & 4.0 & 0.74 & $0.70^{\mathrm{a}}$ \\
\hline & Perimeter road & 3.5 & 1.03 & $0.85^{\mathrm{a}}$ & 3.7 & 0.69 & $0.75^{\mathrm{a}}$ & 3.7 & 0.98 & $0.58^{\mathrm{a}}$ \\
\hline & $\begin{array}{l}\text { Pedestrian } \\
\text { walkways }\end{array}$ & 3.4 & 1.09 & $0.84^{\mathrm{a}}$ & 3.5 & 1.09 & $0.80^{\mathrm{a}}$ & 3.6 & 1.08 & $0.75^{\mathrm{a}}$ \\
\hline & Public phone & 3.4 & 1.08 & $0.71^{\mathrm{a}}$ & 2.9 & 1.22 & $0.72^{\mathrm{a}}$ & 3.8 & 0.86 & $0.72^{\mathrm{a}}$ \\
\hline & Local shops & 3.8 & 0.89 & 0.11 & - & - & - & 3.8 & 1.03 & $0.36^{\mathrm{a}}$ \\
\hline & PFs (8) & 3.6 & 0.66 & 1.00 & 3.4 & 0.72 & 1.00 & 3.8 & 0.54 & 1.00 \\
\hline
\end{tabular}


Table 5 continued

\begin{tabular}{|c|c|c|c|c|c|c|c|c|c|c|}
\hline \multirow[t]{2}{*}{ Components } & \multirow{2}{*}{$\begin{array}{l}\text { Satisfaction } \\
\text { with }\end{array}$} & \multicolumn{3}{|c|}{ Cluster } & \multicolumn{3}{|c|}{ Individual } & \multicolumn{3}{|l|}{ Transit } \\
\hline & & Mean & SD & $\begin{array}{l}\text { Pearson } \\
(r)\end{array}$ & Mean & SD & $\begin{array}{l}\text { Pearson } \\
(r)\end{array}$ & Mean & $\mathrm{SD}$ & $\begin{array}{l}\text { Pearson } \\
(r)\end{array}$ \\
\hline \multirow{5}{*}{$\begin{array}{l}\text { Social environment } \\
\text { (SE) }\end{array}$} & Noise level & 3.4 & 1.04 & $0.83^{\mathrm{a}}$ & 3.7 & 1.01 & $0.78^{\mathrm{a}}$ & 2.8 & 1.18 & $0.79^{\mathrm{a}}$ \\
\hline & $\begin{array}{l}\text { Accident } \\
\text { situation }\end{array}$ & 3.3 & 1.13 & $0.89^{\mathrm{a}}$ & 3.7 & 1.07 & $0.79^{\mathrm{a}}$ & 3.3 & 1.10 & $0.67^{\mathrm{a}}$ \\
\hline & Crime situation & 3.4 & 1.08 & $0.92^{\mathrm{a}}$ & 3.6 & 1.06 & $0.80^{\mathrm{a}}$ & 2.7 & 1.14 & $0.81^{\mathrm{a}}$ \\
\hline & $\begin{array}{l}\text { Community } \\
\text { relations }\end{array}$ & 3.8 & 0.73 & $0.57^{\mathrm{a}}$ & 4.2 & 0.73 & $0.60^{\mathrm{a}}$ & 3.7 & 0.95 & $0.60^{\mathrm{a}}$ \\
\hline & SE (4) & 3.5 & 0.82 & 1.00 & 3.8 & 0.73 & 1.00 & 3.1 & 0.79 & 1.00 \\
\hline \multirow[t]{14}{*}{$\begin{array}{l}\text { Neighbourhood } \\
\text { facilities (NFs) }\end{array}$} & $\begin{array}{l}\text { Distance to town } \\
\text { centre }\end{array}$ & 3.0 & 1.03 & $0.71^{\mathrm{a}}$ & 2.6 & 1.23 & $0.49^{\mathrm{a}}$ & 3.4 & 1.08 & $0.82^{\mathrm{a}}$ \\
\hline & $\begin{array}{l}\text { Distance to } \\
\text { work place }\end{array}$ & 3.3 & 1.06 & $0.62^{\mathrm{a}}$ & 2.9 & 1.43 & $0.68^{\mathrm{a}}$ & 3.1 & 1.23 & $0.80^{\mathrm{a}}$ \\
\hline & $\begin{array}{l}\text { Distance to } \\
\text { school }\end{array}$ & 3.5 & 0.95 & $0.69^{\mathrm{a}}$ & 3.4 & 1.07 & $0.66^{\mathrm{a}}$ & 3.6 & 0.96 & $0.55^{\mathrm{a}}$ \\
\hline & $\begin{array}{l}\text { Distance to } \\
\text { police station }\end{array}$ & 3.3 & 1.12 & $0.74^{\mathrm{a}}$ & 3.7 & 0.85 & $0.52^{\mathrm{a}}$ & 3.4 & 1.12 & $0.85^{\mathrm{a}}$ \\
\hline & $\begin{array}{l}\text { Distance to } \\
\text { hospital/clinic }\end{array}$ & 3.3 & 1.12 & $0.84^{\mathrm{a}}$ & - & - & - & 3.1 & 1.17 & $0.65^{\mathrm{a}}$ \\
\hline & $\begin{array}{l}\text { Distance } \\
\text { shopping } \\
\text { centre }\end{array}$ & 3.2 & 1.04 & $0.85^{\mathrm{a}}$ & - & - & - & 3.4 & 1.05 & $0.78^{\mathrm{a}}$ \\
\hline & $\begin{array}{l}\text { Distance to } \\
\text { market }\end{array}$ & 3.3 & 1.02 & $0.85^{\mathrm{a}}$ & - & - & - & 3.4 & 1.08 & $0.79^{\mathrm{a}}$ \\
\hline & $\begin{array}{l}\text { Distance to } \\
\text { public library }\end{array}$ & 3.3 & 1.12 & $0.75^{\mathrm{a}}$ & 3.6 & 0.92 & $0.57^{\mathrm{a}}$ & 2.7 & 1.34 & $0.61^{\mathrm{a}}$ \\
\hline & $\begin{array}{l}\text { Distance to } \\
\text { mosque }\end{array}$ & 3.8 & 0.94 & $0.65^{\mathrm{a}}$ & 3.9 & 0.88 & $0.55^{\mathrm{a}}$ & 3.7 & 1.06 & $0.68^{\mathrm{a}}$ \\
\hline & $\begin{array}{l}\text { Distance to LRT } \\
\text { station }\end{array}$ & 1.6 & 0.82 & $0.48^{\mathrm{a}}$ & 1.6 & 2.8 & 0.20 & 1.8 & 0.74 & $0.33^{\mathrm{a}}$ \\
\hline & $\begin{array}{l}\text { Distance to bus } \\
\text { station }\end{array}$ & 3.2 & 0.89 & $0.43^{\mathrm{a}}$ & 2.3 & 1.23 & $0.58^{\mathrm{a}}$ & 3.2 & 1.13 & $0.61^{\mathrm{a}}$ \\
\hline & $\begin{array}{l}\text { Distance to taxi } \\
\text { stand }\end{array}$ & 2.6 & 1.16 & $0.42^{\mathrm{a}}$ & 1.5 & 1.01 & $0.55^{\mathrm{a}}$ & 3.0 & 1.23 & $0.66^{\mathrm{a}}$ \\
\hline & $\begin{array}{l}\text { Distance to fire } \\
\text { station }\end{array}$ & 3.0 & 1.10 & $0.61^{\mathrm{a}}$ & 1.5 & 1.01 & $0.34^{\mathrm{b}}$ & 3.0 & 1.12 & $0.71^{\mathrm{a}}$ \\
\hline & NFs (13) & 3.1 & 0.69 & 1.00 & 2.6 & 0.55 & 1.00 & 3.1 & 0.76 & 1.00 \\
\hline \multicolumn{2}{|c|}{ Overall housing satisfaction (45) } & 3.4 & 0.46 & - & 3.3 & 0.45 & - & 3.3 & 0.50 & - \\
\hline
\end{tabular}

Source: Field Survey, 2009

Bold figures indicate housing component values

a Significant at 0.001 level

b Significant at 0.05 level

The distribution of the regime of satisfaction (Fig. 2) shows that a moderate level of housing satisfaction is dominant for most of the components. The exceptions are the neighbourhood facilities among people in individual housing and housing support services among those in cluster housing. A significantly higher percentage of respondents expressed 


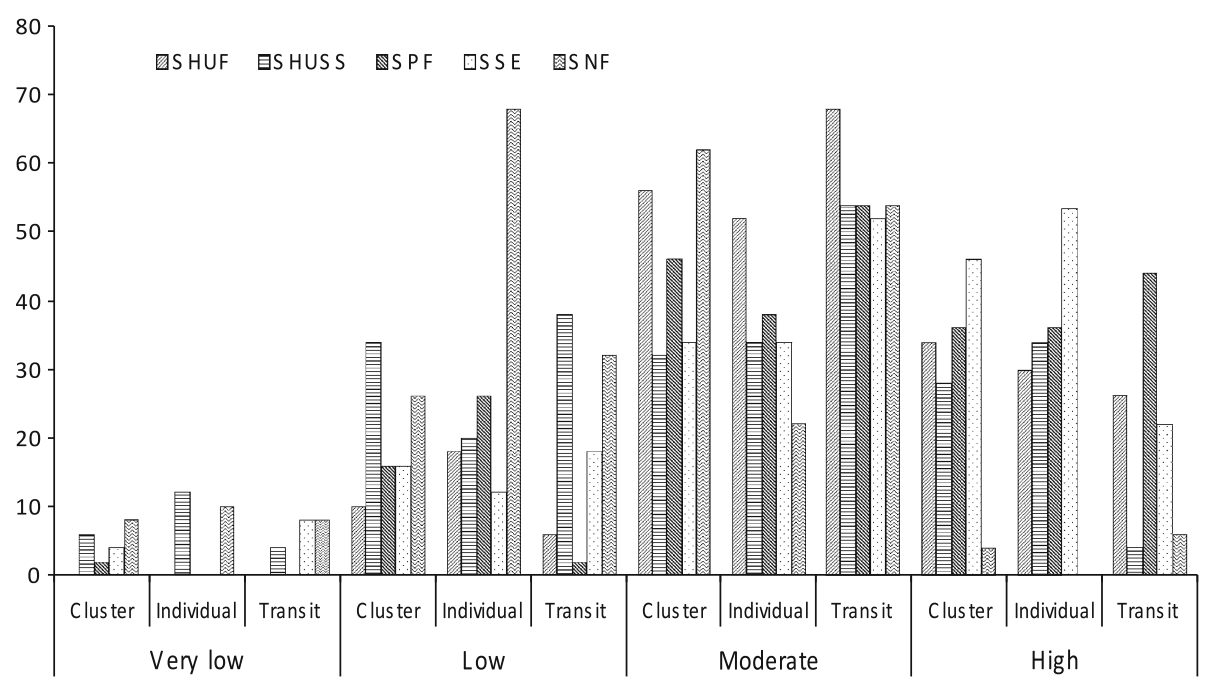

Fig. 2 Percentage distribution of respondents by housing types and regime of satisfaction. Notes: Regime of satisfaction: Very low $=20-39.9 ;$ Low $=40-59.9 ;$ Moderate $=60-79.9 ;$ High, 80-100. SHUF, satisfaction with housing unit features; SHUSS, satisfaction with housing unit support services; SPF, satisfaction with public facilities; SSE, satisfaction with social environment; SNF, satisfaction with neighbourhood facilities

a lower level of satisfaction with the public facilities component in the individual and cluster housing schemes. On the contrary, high satisfaction levels with the social environment component were recorded among cluster and individual housing residents, followed by a higher satisfaction with public facilities among the transit housing dwellers. Also significantly high levels of satisfaction have been expressed about the public facilities component by individual and cluster housing inhabitants, followed by satisfaction with housing unit features expressed by cluster housing residents and with housing support services expressed by individual housing dwellers. A significant percentage of cluster and individual housing residents revealed high satisfaction with housing unit features and support services compared to the transit housing residents, in which case the percentage of respondents is relatively low.

\subsection{Analysis of habitability indices and housing environment}

Habitability indices (HI) are calculated to assess the contribution of specific variables to the degree of satisfaction or dissatisfaction of the respondents (Ogu 2002). In order to facilitate the interpretation of the contribution of housing and other environmental variables to the degree of satisfaction or dissatisfaction expressed by the respondents living in three types of housing schemes, habitability indices are categorised into three broad regions - highly positive $(++)$ with index values between 70 and 100; moderately positive $(+)$ with index values between 60 and 69.9; and negative $(-)$ with index values between 20 and 59.9. Table 6 shows that the individual housing dwellers are dissatisfied with $23 \%$ of all items, followed by the transit housing dwellers, who are dissatisfied with $21 \%$ of all items. On the other hand, the cluster housing residents reported the lowest level of dissatisfaction, being dissatisfied with $9 \%$ of all items. Component-wise distribution shows that the transit housing respondents expressed dissatisfaction about the bathroom, (clothes) 
Table 6 Distribution of habitability indices by housing types and regions of habitability

\begin{tabular}{|c|c|c|c|c|c|c|c|}
\hline \multirow[t]{2}{*}{ Components } & \multirow[t]{2}{*}{ Variables } & \multicolumn{6}{|c|}{ Habitability Indices and Regions } \\
\hline & & Cluster & Regions & Individual & Regions & Transit & Regions \\
\hline \multirow{11}{*}{$\begin{array}{l}\text { Housing unit features } \\
\text { (HUFs) }\end{array}$} & Living area & 68.0 & + & 69.6 & + & 79.6 & ++ \\
\hline & Dinning space & 66.4 & + & 64.4 & + & 63.2 & + \\
\hline & Kitchen space & 68.0 & + & 68.4 & + & 68.0 & + \\
\hline & Bedroom-1 & 78.0 & ++ & 74.8 & ++ & 86.0 & ++ \\
\hline & Bedroom-2 & 78.0 & ++ & 74.4 & ++ & 86.0 & ++ \\
\hline & Bedroom-3 & 74.4 & ++ & 61.2 & + & 80.8 & ++ \\
\hline & Toilet & 72.4 & ++ & 70.0 & ++ & 74.8 & ++ \\
\hline & Bathroom & 66.0 & + & 62.0 & + & 56.0 & - \\
\hline & $\begin{array}{l}\text { (Clothes) Drying } \\
\text { area }\end{array}$ & 69.6 & + & 72.4 & ++ & 50.4 & - \\
\hline & $\begin{array}{l}\text { (Power) Socket } \\
\text { points }\end{array}$ & 65.6 & + & 70.0 & ++ & 72.4 & ++ \\
\hline & Ventilation & 71.6 & ++ & 78.0 & ++ & 72.8 & ++ \\
\hline \multirow{9}{*}{$\begin{array}{l}\text { Housing unit support } \\
\text { services (HUSSs) }\end{array}$} & Corridor & $\mathrm{n} / \mathrm{a}$ & $\mathrm{n} / \mathrm{a}$ & $\mathrm{n} / \mathrm{a}$ & $\mathrm{n} / \mathrm{a}$ & 61.6 & + \\
\hline & Staircase & $\mathrm{n} / \mathrm{a}$ & $\mathrm{n} / \mathrm{a}$ & $\mathrm{n} / \mathrm{a}$ & $\mathrm{n} / \mathrm{a}$ & 62.4 & + \\
\hline & Lift lobby & $\mathrm{n} / \mathrm{a}$ & $\mathrm{n} / \mathrm{a}$ & $\mathrm{n} / \mathrm{a}$ & $\mathrm{n} / \mathrm{a}$ & 42.4 & - \\
\hline & Lift & $\mathrm{n} / \mathrm{a}$ & $\mathrm{n} / \mathrm{a}$ & $\mathrm{n} / \mathrm{a}$ & $\mathrm{n} / \mathrm{a}$ & 43.6 & - \\
\hline & Fire fighting & $\mathrm{n} / \mathrm{a}$ & $\mathrm{n} / \mathrm{a}$ & $\mathrm{n} / \mathrm{a}$ & $\mathrm{n} / \mathrm{a}$ & 48.4 & - \\
\hline & Cleanliness of drains & 66.4 & + & 61.2 & + & 59.6 & - \\
\hline & Street lighting & 63.6 & + & 70.0 & ++ & 76.4 & ++ \\
\hline & Garbage collection & 64.0 & + & 67.6 & + & 74.0 & ++ \\
\hline & $\begin{array}{l}\text { Cleanliness of garb } \\
\text { house }\end{array}$ & 62.0 & + & 59.6 & - & 70.0 & ++ \\
\hline \multirow[t]{8}{*}{ Public facilities (PFs) } & Open space/play area & 66.8 & + & 60.0 & + & 74.8 & ++ \\
\hline & Car/M'cycle parking & 69.6 & + & 66.8 & + & 79.6 & ++ \\
\hline & Prayer hall & 82.0 & ++ & 86.0 & ++ & 88.0 & ++ \\
\hline & Multi-purpose hall & 76.0 & ++ & 74.8 & ++ & 82.0 & ++ \\
\hline & Perimeter road & 70.8 & ++ & 74.8 & ++ & 73.6 & ++ \\
\hline & Pedestrian walkways & 68.4 & + & 69.2 & + & 72.0 & ++ \\
\hline & Public phone & 67.6 & + & 58.8 & - & 75.6 & ++ \\
\hline & Local shops & 76.5 & ++ & $\mathrm{n} / \mathrm{a}$ & $\mathrm{n} / \mathrm{a}$ & 76.8 & ++ \\
\hline \multirow[t]{4}{*}{ Social environment } & Noise level & 67.6 & + & 73.2 & ++ & 55.6 & - \\
\hline & Accident situation & 66.4 & + & 73.6 & ++ & 65.6 & + \\
\hline & Crime situation & 67.6 & + & 72.4 & ++ & 54.8 & - \\
\hline & Community relations & 76.0 & ++ & 84.4 & ++ & 74.0 & ++ \\
\hline \multirow[t]{4}{*}{$\begin{array}{l}\text { Neighbourhood facilities } \\
\text { (NFs) }\end{array}$} & $\begin{array}{l}\text { Distance to town } \\
\text { centre }\end{array}$ & 60.8 & + & 52.0 & - & 68.0 & + \\
\hline & $\begin{array}{l}\text { Distance to work } \\
\text { place }\end{array}$ & 65.2 & + & 57.2 & - & 62.8 & + \\
\hline & Distance to school & 70.8 & ++ & 68.8 & + & 72.4 & ++ \\
\hline & $\begin{array}{l}\text { Distance to police } \\
\text { station }\end{array}$ & 65.2 & + & 74.8 & ++ & 67.2 & + \\
\hline
\end{tabular}


Table 6 continued

\begin{tabular}{|c|c|c|c|c|c|c|c|}
\hline \multirow[t]{2}{*}{ Components } & \multirow[t]{2}{*}{ Variables } & \multicolumn{6}{|c|}{ Habitability Indices and Regions } \\
\hline & & Cluster & Regions & Individual & Regions & Transit & Regions \\
\hline & $\begin{array}{l}\text { Dist'ce to hospital/ } \\
\text { clinic }\end{array}$ & 65.2 & + & $\mathrm{n} / \mathrm{a}$ & $\mathrm{n} / \mathrm{a}$ & 61.6 & + \\
\hline & $\begin{array}{l}\text { Dist'ce to shopping } \\
\text { centre }\end{array}$ & 64.8 & + & $\mathrm{n} / \mathrm{a}$ & $\mathrm{n} / \mathrm{a}$ & 68.4 & + \\
\hline & Distance to market & 66.8 & + & $\mathrm{n} / \mathrm{a}$ & $\mathrm{n} / \mathrm{a}$ & 67.2 & + \\
\hline & $\begin{array}{l}\text { Distance to public } \\
\text { library }\end{array}$ & 65.2 & + & 71.6 & ++ & 54.4 & - \\
\hline & Distance to masjid & 76.4 & ++ & 77.2 & ++ & 73.2 & ++ \\
\hline & $\begin{array}{l}\text { Distance to LRT } \\
\text { station }\end{array}$ & 32.8 & - & 20.4 & - & 35.2 & - \\
\hline & $\begin{array}{l}\text { Distance to bus } \\
\text { station }\end{array}$ & 64.8 & + & 46.8 & - & 64.4 & + \\
\hline & Distance to taxi stand & 51.2 & - & 29.6 & - & 60.4 & + \\
\hline & $\begin{array}{l}\text { Distance to fire } \\
\text { station }\end{array}$ & 59.2 & - & 30.4 & - & 60.4 & + \\
\hline
\end{tabular}

Source: Field Survey, 2009

Regions of habitability: negative $(-)=<60$; moderately positive $(+)=60-69.9$; highly positive $(++)=70-100 ; \mathrm{n} / \mathrm{a}=$ not applicable

drying area, lift and lift lobby, fire fighting, cleanliness of drains, noise level, crime situation and distance to the public library and LRT station. The component-wise distribution also shows dissatisfaction among individual housing dwellers regarding the cleanliness of the garbage house, public phone and the distance to the town centre, workplaces, fire station and public transport facilities. On the other hand, cluster housing residents conveyed their dissatisfaction with most of the public transport services, including the location of the fire station.

\subsection{Multivariate analysis of housing satisfaction}

The Pearson correlation matrix (Table 7) shows that the OCHSI (Overall Cluster Housing Satisfaction Index) is more highly positively correlated to public facilities, housing unit support services and neighbourhood facilities than to social environment and housing unit features, where the $r$ values are significantly positive but low. The OIHSI (Overall Individual Housing Satisfaction Index) is highly positively correlated to housing unit features, support services, public facilities and social environment, though it has a low correlation with neighbourhood facilities. The OTHSI (Overall Transit Housing Satisfaction Index) has high positive correlations with all the components. Inter-component correlation analysis (Table 7) indicates that satisfaction with housing unit features has positive correlations with housing support services, public facilities and social environment for all housing groups except the social environment component of the cluster housing group. However, satisfaction with neighbourhood facilities has no correlation with satisfaction about housing unit features. Satisfaction with housing unit support services is positively correlated to satisfaction with public facilities, social environment 
Table 7 Correlation matrix between overall housing satisfaction and satisfaction components

\begin{tabular}{|c|c|c|c|c|c|c|c|}
\hline COMPONENT & Housing schemes & OHSI & SIHUF & SIHUSS & SIPF & SISE & SINF \\
\hline \multirow[t]{3}{*}{ OHSI } & Cluster & 1 & $0.56^{\mathrm{a}}$ & $0.76^{\mathrm{a}}$ & $0.78^{\mathrm{a}}$ & $0.57^{\mathrm{a}}$ & $0.72^{\mathrm{a}}$ \\
\hline & Individual & 1 & $0.82^{\mathrm{a}}$ & $0.77^{\mathrm{a}}$ & $0.76^{\mathrm{a}}$ & $0.60^{\mathrm{a}}$ & $0.45^{\mathrm{a}}$ \\
\hline & Transit & 1 & $0.72^{\mathrm{a}}$ & $0.80^{\mathrm{a}}$ & $0.83^{\mathrm{a}}$ & $0.70^{\mathrm{a}}$ & $0.80^{\mathrm{a}}$ \\
\hline \multirow[t]{3}{*}{ SIHUF } & Cluster & & 1 & $0.44^{\mathrm{a}}$ & $0.34^{\mathrm{b}}$ & - & - \\
\hline & Individual & & 1 & $0.50^{\mathrm{a}}$ & $0.56^{\mathrm{a}}$ & $0.52^{\mathrm{a}}$ & - \\
\hline & Transit & & 1 & $0.65^{\mathrm{a}}$ & $0.63^{\mathrm{a}}$ & $0.39^{\mathrm{a}}$ & - \\
\hline \multirow[t]{3}{*}{ SIHUSS } & Cluster & & & 1 & $0.72^{\mathrm{a}}$ & $0.50^{\mathrm{a}}$ & - \\
\hline & Individual & & & 1 & $0.55^{\mathrm{a}}$ & $0.40^{\mathrm{a}}$ & $0.31^{\mathrm{b}}$ \\
\hline & Transit & & & 1 & $0.63^{\mathrm{a}}$ & $0.43^{\mathrm{a}}$ & $0.44^{\mathrm{a}}$ \\
\hline \multirow[t]{3}{*}{ SIPF } & Cluster & & & & 1 & $0.59^{\mathrm{a}}$ & $0.28^{\mathrm{b}}$ \\
\hline & Individual & & & & 1 & $0.43^{\mathrm{a}}$ & - \\
\hline & Transit & & & & 1 & $0.63^{\mathrm{a}}$ & $0.52^{\mathrm{a}}$ \\
\hline \multirow[t]{3}{*}{ SISE } & Cluster $\mathrm{r}$ & & & & & 1 & - \\
\hline & Individual & & & & & 1 & - \\
\hline & Transit & & & & & 1 & $0.52^{\mathrm{a}}$ \\
\hline \multirow[t]{3}{*}{ SINF } & Cluster $r$ & & & & & & 1 \\
\hline & Individual & & & & & & 1 \\
\hline & Transit & & & & & & 1 \\
\hline
\end{tabular}

Source: Field Survey, 2009

OHSI overall housing satisfaction index, SIHUF satisfaction index with housing unit features, SIHUSS satisfaction index with housing unit support services, SIPF satisfaction index with public facilities, SISE satisfaction index with social environment, SINF satisfaction index with neighbourhood facilities

a Significant at 0.01 level

b Significant at 0.05 level

c Significant at 0.10 level

and neighbourhood facilities for all the housing categories. The only exception appears to be the satisfaction with neighbourhood facilities among the cluster housing group. Satisfaction with public facilities is positively correlated to satisfaction with the social environment and neighbourhood facilities for all housing groups. The only exception concerns the individual housing group, having no correlation with satisfaction about neighbourhood facilities. Satisfaction about the social environment has no correlation with satisfaction about neighbourhood facilities among any housing category. The respondents' socio-economic characteristics offered no meaningful correlations with the five housing satisfaction components.

Three Multiple Linear Regression (MLR) models were estimated to determine the best linear combination of independent variables for predicting the overall housing satisfaction of each housing group. For the overall cluster housing satisfaction (MLR-1; Table 8), the model identified nine predictor variables with beta weights. Of these nine, two belong to housing unit features, two to housing unit support services, three to public facilities and two to neighbourhood facilities. The model suggests that cluster housing residents' overall satisfaction can be enhanced by improving satisfaction about the distance to market, public 
Table 8 Multiple linear regression (MLR-1) model of overall housing satisfaction index (Cluster Type) with housing satisfaction variables

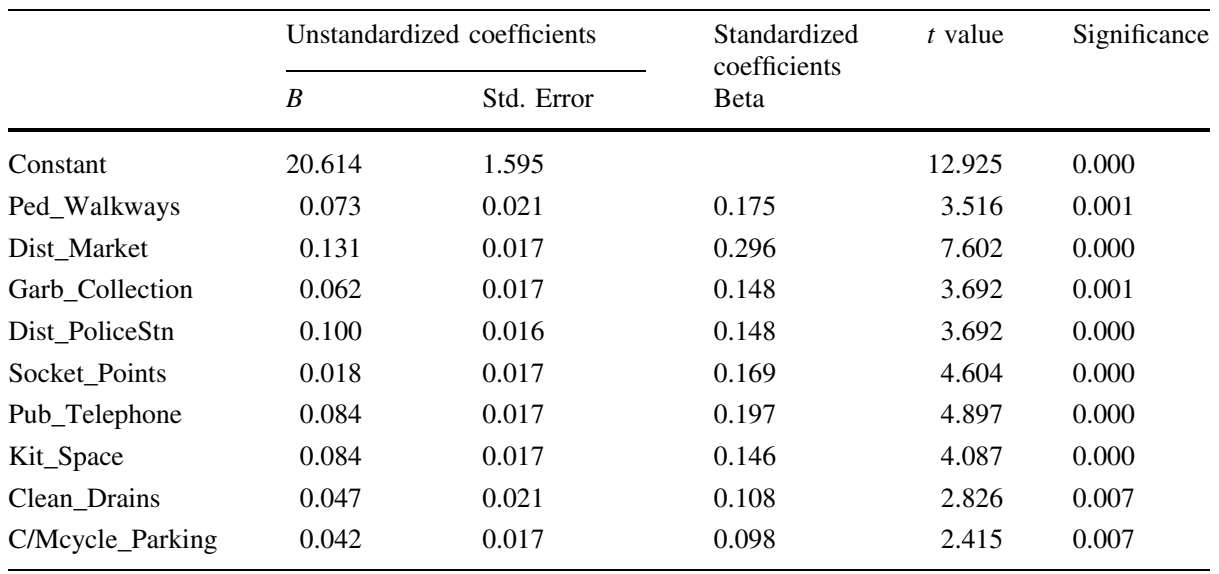

$R=.98 ; R^{2}=.96 ;$ adjusted $R^{2}=.95 ;$ Std error of estimate $=1.90801 ;$ significance $=.020$

Dependent variable $=$ overall housing satisfaction index for cluster housing scheme (OHSIC)

Ped_Walkways, Satisfaction with Pedestrian Walkways; Dist_Market, Satisfaction with Distance to Market; Garb_Collection, Satisfaction with garbage collection; Dist_PoliceStn, Satisfaction with Distance to police station; Socket_Points, Satisfaction with socket points in the house; Pub_Telephone, Satisfaction with public telephone; Kit_Space, Satisfaction with kitchen space (area); Clean_Drains, Satisfaction with cleanliness of drains; C/Mcycle_Parking, Satisfaction with car/motorcycle parking

telephone, pedestrian walkways, (power) socket points, garbage collection, distance to police station, kitchen space, cleanliness of drains and parking facilities.

For overall individual housing satisfaction (MLR-2; Table 9), the model identified eight predictor variables with beta weights. Of these eight, two belong to housing unit features, three to housing support services and one each to public and neighbourhood facilities. The model suggests that individual housing residents' total housing satisfaction can be enhanced by improving satisfaction with the kitchen space, distance to school, street lighting, parking, cleanliness of the garbage house, cleanliness of drains, pedestrian walkways and the (clothes) drying area.

For the overall transit housing satisfaction (MLR-3; Table 10), the model identified nine predictor variables with beta weights. Of the nine variables, only one belongs to the housing unit features, three belong to housing support services, two are public facilities, one is part of the social environment and two are neighbourhood facilities. It appears from the model that transit housing residents' total housing satisfaction can be enhanced by improving their satisfaction about the distance to the workplace, about pedestrian walkways, the living area, the distance to the police station, the lift lobby, the multi-purpose hall, the noise level, street lighting and garbage collection.

\section{Conclusions and recommendations}

The paper reveals that the residents of the three types of social housing provided by the SZB have a differential rating of satisfaction with five components and forty-five variables. All the residents have expressed moderate satisfaction with the housing unit component but low satisfaction with the house support services component. Moreover, while both transit 
Table 9 Multiple linear regression (MLR-2) model of overall housing satisfaction index (Individual Type) with housing satisfaction variables

\begin{tabular}{|c|c|c|c|c|c|}
\hline & \multicolumn{2}{|c|}{ Unstandardized Coefficients } & \multirow{2}{*}{$\begin{array}{l}\text { Standardized Coefficients } \\
\text { Beta }\end{array}$} & \multirow[t]{2}{*}{$t$ value } & \multirow[t]{2}{*}{ Significance } \\
\hline & $B$ & Std. Error & & & \\
\hline Constant & 21.729 & 2.208 & & 9.841 & 0.000 \\
\hline GarH_clean & 0.065 & 0.078 & 0.173 & 2.391 & 0.021 \\
\hline Kit_space & 0.131 & 0.024 & 0.282 & 5.360 & 0.000 \\
\hline Dist_School & 0.092 & 0.020 & 0.218 & 4.559 & 0.000 \\
\hline Ped_Walkways & 0.057 & 0.026 & 0.139 & 2.243 & 0.030 \\
\hline Clean_Drains & 0.069 & 0.026 & 0.163 & 2.762 & 0.009 \\
\hline Street_lighting & 0.104 & 0.029 & 0.209 & 3.590 & 0.001 \\
\hline C/Mcycle_Parking & 0.067 & 0.025 & 0.184 & 2.727 & 0.009 \\
\hline Dry_area & 0.061 & 0.026 & 0.134 & 2.343 & 0.024 \\
\hline
\end{tabular}

$R=.96 ; R^{2}=.92 ;$ adjusted $R^{2}=.90 ;$ Std error of estimate $=2.7587 ;$ significance $=.010$

Dependent variable $=$ overall housing satisfaction index for individual housing scheme (OHSII)

GarH_clean, Satisfaction with cleanliness of Garbage house; Kit_space, Satisfaction with kitchen space (area); Dist_school, Satisfaction with distance to school; Ped_walkways, Satisfaction with pedestrian walkways; Clean_Drain, Satisfaction with cleanliness of drains; Street_lighting, Satisfaction with street lighting; C/Mcycle_parking, Satisfaction with car/motorcycle parking; Dry_Area, Satisfaction with (clothes) drying area

Table 10 Multiple linear regression (MLR-3) model of overall housing satisfaction index (Transit Type) with housing satisfaction variables

\begin{tabular}{|c|c|c|c|c|c|}
\hline & \multicolumn{2}{|c|}{ Unstandardized coefficients } & \multirow{2}{*}{$\begin{array}{l}\text { Standardized coefficients } \\
\text { Beta }\end{array}$} & \multirow[t]{2}{*}{$t$ value } & \multirow[t]{2}{*}{ Significance } \\
\hline & $B$ & Std. Error & & & \\
\hline Constant & 6.863 & 2.244 & & 3.058 & 0.004 \\
\hline Dist_Workplace & 0.097 & 0.019 & 0.238 & 5.075 & 0.000 \\
\hline Ped_Walkways & 0.115 & 0.020 & 0.238 & 5.797 & 0.000 \\
\hline Garb_Collection & 0.069 & 0.023 & 0.113 & 3.032 & 0.004 \\
\hline Liv_area & 0.154 & 0.021 & 0.237 & 7.404 & 0.000 \\
\hline Noise & 0.067 & 0.015 & 0.158 & 4.491 & 0.000 \\
\hline Multi_hall & 0.115 & 0.021 & 0.170 & 4.811 & 0.000 \\
\hline Dist_PoliceStn & 0.087 & 0.020 & 0.194 & 4.443 & 0.000 \\
\hline Lift_lobby & 0.080 & 0.016 & 0.191 & 4.982 & 0.000 \\
\hline Street_lighting & 0.081 & 0.027 & 0.122 & 3.050 & 0.004 \\
\hline
\end{tabular}

$R=.98 ; R^{2}=.96 ;$ adjusted $R^{2}=.95 ;$ Std error of estimate $=2.01732 ;$ significance $=.004$

Dependent variable $=$ overall housing satisfaction index for transit housing scheme (OHSIT)

Dist_Workplace, Satisfaction with Distance to Workplace; Ped_Walkways, Satisfaction with Pedestrian Walkways; Garb_collection, Satisfaction with Garbage collection; Liv_area, Satisfaction with living area; Noise, Satisfaction with noise; Multi_hall, Satisfaction with multi-purpose hall; Dist_PoliceStn, Satisfaction with Distance to police station; Lift_lobby, Satisfaction with lift lobby; Street_lighting, Satisfaction with street lighting 
and cluster housing residents were moderately satisfied about the public facilities, the individual housing group reported a lower level of satisfaction with that component. Again, while both individual and cluster housing residents were moderately satisfied with the social environment, transit housing residents showed low satisfaction with that component. Further, while individual housing residents expressed dissatisfaction with neighbourhood facilities, both transit and cluster resident groups conveyed very low satisfaction with that component. The distribution of the regime of satisfaction shows that a moderate level of housing satisfaction predominates for most of the components, except for the rating of neighbourhood facilities by the individual housing group and of housing support services by the cluster housing group. The component-wise distribution of habitability indices shows that the transit housing respondents have expressed dissatisfaction with the bathroom, (clothes) drying area, lift and lift lobby, fire fighting, cleanliness of drains, noise level, crime situation and the distance to the public library and LRT station. Individual housing dwellers conveyed their dissatisfaction with the cleanliness of the garbage house, the public phone and with the distance to the town centre, workplaces, fire station and public transport facilities. On the other hand, cluster housing residents conveyed their dissatisfaction about most of the public transport services, including the location of the fire station. The three Multiple Linear Regression (MLR) models that were estimated show that the cluster housing residents' overall housing satisfaction can be enhanced by improving satisfaction with the distance to the market, public telephone, pedestrian walkways, socket points, garbage collection, distance to the police station, kitchen space, cleanliness of drains and the parking facility. These MLR models also show that individual housing residents' total housing satisfaction can be enhanced through improving satisfaction with the kitchen space, distance to school, street lighting, parking, cleanliness of the garbage house, cleanliness of drains, pedestrian walkways and the (clothes) drying area. The models further show that transit housing residents' total housing satisfaction can be enhanced by improving their satisfaction with the distance to the workplace, pedestrian walkways, living area, distance to police station, lift lobby, multi-purpose hall, noise level, street lighting and garbage collection.

It appears that Selangor Zakat Board's endeavour to provide housing to the poor has been successful, though only in terms of the provision of the housing unit. One indicator of this success is that $78 \%$ of transit and $84 \%$ of cluster and individual residents have expressed their desire not to move away from their current residences. The majority of the transit group expressed concern about the size of their houses, which they consider small. In fact, our analysis (Table 4) shows that the average family in all three housing types consists of more than five persons. Actually, more than half (58-66\%) of the respondents have $6+$ family members. The policy implication of this is that SZB should adopt the criterion of family size in determining the size of the house, particularly the number of bedrooms. Transit housing appears to be successful, with residents who are satisfied about the housing unit features and public facilities, because of their location in urban areas. With respect to satisfaction about housing support services, the social environment and neighbourhood facilities, there is a need for improvement. Individual housing seems to be successful, with satisfaction about the social environment, housing unit features, public facilities and housing support services. But due to the location in rural areas, dissatisfaction prevails about neighbourhood facilities that require improvement. Cluster housing tends to be successful with regard to housing unit features, public facilities and the social environment, but housing support services and neighbourhood facilities require improvement in order to enhance residents' satisfaction. The above 
analysis leads to three policy implications for SZB in the provision of social housing for the poor:

(a) A significant percentage of the units in each housing scheme should be built for large $(6+)$ families;

(b) SZB should adopt a 'bundle approach' to provide housing along with other facilities;

(c) SZB should select the location for housing units based on where non-sheltered facilities exist.

Whereas the first two policies have financial implications, the third policy would require SZB to select locations of housing in areas where proper public and other facilities are available. Some techniques to assess suitability pertaining to the location of housing units can be used to determine areas of high potential from the perspective of the availability of public, neighbourhood and social facilities.

Open Access This article is distributed under the terms of the Creative Commons Attribution Noncommercial License which permits any noncommercial use, distribution, and reproduction in any medium, provided the original author(s) and source are credited.

\section{References}

Alison, P., Kearns, A., \& Atkinson, R. (2002). What makes people dissatisfied with their neighbourhoods? Urban Studies, 39(13), 2413-2438.

Al-Qardawi, \& Yusuf, A. (2006). Economic security in Islam, (Translation by Muhammad Iqbal Siddiqi). New Delhi, India: Islamic Book Service.

Amerigo, M., \& Aragones, J. M. (1997). A theoretical and methodological approach to the study of residential satisfaction. Journal of Environmental Psychology, 17, 47-57.

Barcus, H. R. (2004). Urban-rural Migration in the USA: An analysis of residential satisfaction. Regional Studies, 38(6), 643-657.

Djebarni, R., \& Al-Abed, A. (2000). Satisfaction level with neighbourhood in low-income public housing in Yemen. Property Management, 18(4), 230-242.

Elsinga, M., \& Hoekstra, J. (2005). Homeownership and housing satisfaction. Journal of Housing and the Built Environment, 20, 401-424.

Francescato, G., Weidemann, S., \& Anderson, J. R. (1987). Residential satisfaction: Its uses and limitations in housing research. In W. V. Vliet, H. Choldin, W. Michelson, \& P. Popene (Eds.), Housing and neighbourhood: Theoretical and empirical contributions (pp. 43-57). Connecticut: Greenwood Press.

Galster, G. C. (1987). Identifying the correlates of dwelling satisfaction: An empirical critique. Environment and Behavior, 19(5), 539-568.

Husna, S., \& Nurizan, Y. (1987). Housing provision and satisfaction of low-income households in Kuala Lumpur. Habitat International, 11(4), 27-38.

Kaitilla, S. (1993). Satisfaction with public housing in Papua New Guinea. Environment and Behavior, 25(4), 514-545.

Lane, S., \& Kinsey, J. (1980). Housing tenure and housing satisfaction. Journal of Consumer Affairs, 14, 341-365.

Loo, C. (1986). Neighborhood satisfaction and safety: A study of low-income ethnic area. Environment and Behavior, 18(1), 109-131.

Lu, M. (1999). Determinants of residential satisfaction: Ordered logit vs regression models. Growth and Change, 30, 264-287.

Lu, M. (2002). Are pastures greener? Residential consequences of migration. International Journal of Population Geography, 8, 201-216.

Mohit, M. A., Ibrahim, M., \& Razita, Y. (2010). Assessment of residential satisfaction of newly designed public low-cost housing in Kuala Lumpur, Malaysia. Habitat International, 34(1), 18-27.

Morris, E. W., \& Winter, M. (1975). A theory of family housing adjustment. Journal of Marriage and the Family, 37, 79-88.

Morris, E. W., \& Winter, M. (1978). Housing, family and society. New York: Wiley. 
Nurizan, Y. (1993). Space deficit in low-cost household of Peninsular Malaysia. Kajian Malaysia, 11(1), $56-75$.

Nurizan, Y., \& Hashim, A. H. (2001). Perumahan dan Kediaman. Malaysia: Universiti Putra Malaysia.

Ogu, V. I. (2002). Urban residential satisfaction and the planning implications in a developing world context: The example of Benin City, Nigeria. International Planning Studies, 7(1), 37-53.

Razali, A. (1993). Transit house: Privatization of low-cost housing in Peninsular Malaysia. In International seminar and exhibition on low-cost housing. Penang: Universiti Sains Malaysia.

Rossi, P. H. (1955). Why families move? Glencoe. Illinois: The Free Press.

Russell, N. J. (2007). Multifamily housing characteristics and tenant satisfaction. Journal of Performance of Constructed Facilities, 21(6), 472-480.

Russell, N. J. (2008a). Residential satisfaction of elderly tenants in apartment housing. Social Indicator Research, 89, 421-437.

Russell, N. J. (2008b). Impact of subsidized rental housing characteristics of metropolitan residential satisfaction. Journal of Urban Planning and Development, 134(4), 166-172.

Salleh, A. G. (2008). Neighbourhood factors in private low-cost housing in Malaysia. Habitat International, 32(4), 485-494.

Savasdisara, T., Tips, W. E. J., \& Suwannodom, S. (1989). Residential satisfaction in private estates in Bangkok: A comparison of low-cost housing estates and determinant factors. Habitat International, 13(1), 65-73.

SZB. (2008). Asnaf magazine, SZB. Malaysia: Shah Alam.

Tan, S. H. (1980). Factors influencing the location, layout and scale of low-cost housing in Malaysia. In S. H. Tan \& H. Sendur (Eds.), Public and private housing in Malaysia. Kuala Lumpur: Heinemann Educational Books (Asia) Ltd.

Ukoha, O. M., \& Beamish, J. O. (1997). Assessment of resident's satisfaction with public housing in Abuja, Nigeria. Habitat International, 21(4), 445-460.

Varady, D. P., \& Carrozza, M. A. (2000). Towards a better way to measure customer satisfaction levels in public housing: A report from Cincinnati. Housing Studies, 15(6), 797-825.

Jaafar, M., Hasan, N. L., Mohamad, O., Ramayah, T. (undated). The determinants of housing satisfaction level: A study of residential development project by Penang Development Corporation. Malaysia: Universiti Sains Malaysia.

Yang, Y. (2008). A tale of two cities-Physical form and neighborhood satisfaction in Metropolitan Portland and Charlotte. Journal of the American Planning Association, 74(3), 307-324. 